

\section{Closing the Loop: Corporate Links to the Voluntary \\ Sector}

This paper brings together findings from three separate investigations to provide a deeper understanding of the changing roles of the government, for-profit and nonprofit sectors in ensuring civil society. The first study, based on a survey of 645 nonprofit organizations from across Canada, revealed a nonprofit sector changing to meet the challenges of the times, despite a general pessimism among leaders of nonprofit organizations as to their future (Meinhard \& Foster, 2003a \& b). The second, based on interviews with 20 Government of Ontario officials with links to the nonprofit sector, demonstrated how civil servants struggled to help nonprofit organizations adjust to the new policies and also encouraged them to form partnerships with the for-profit sector (Meinhard \& Foster, 2003c). The research reported in this paper, based on interviews with 17 senior officers of Ontario-based corporations active in philanthropy, focuses on the corporations and probes more deeply into the myriad of ways they are getting involved in their communities as socially responsible corporate citizens. The findings from these corporate interviews are compared and melded with those from previous interviews with government officials and nonprofit organizations to provide a threedimensional perspective of the direction in which Canadian civil society may be moving.

\section{Setting the Context}

During the three decades immediately following WWII, Canadian social policy concentrated on establishing a broad and expansive welfare state, based on a partnership with the voluntary sector. The construction of this nation-wide social welfare system was largely completed by the mid-1970s. The system involved a matrix of programs and services that were delivered by both the public and voluntary sectors. Nonprofit organizations were part of the elaborate system that was created to extend specialized services to the public. Since the mid-1980s however, the political philosophy in Canada has been shifting from a pluralist, social welfare conception of State to a neo-conservative philosophy (McBride and Shields, 1997; Jeffrey, 1999). The partnership between government and the voluntary sector has been gradually eroding, having fallen victim to the political ideology that less government is better (Pal, 1997). The past two decades have been characterized by fiscal restraint, privatization of government services and drastic funding cuts to the voluntary sector. The unique relationship between government and the voluntary sector in pursuing a shared vision of serving the needy has been replaced by contractual arrangements through competitive bidding, where nonprofit agencies compete with for-profit businesses (Ryan, 1999, Weisbrod, 1995; Pal, 1997).

These changes have "seriously reduced the capacity for voluntary agencies to provide services" (Rice \& Prince, 2000:113). Paid positions were lost and recruitment and training had to be curtailed. Forced commercialization, introduction of fees for service, adoption of business practices, and marketing and fundraising strategies, led to mission displacement. A sense of vulnerability reduced the role of advocacy and networking for policy changes (Rice \& Prince, 
2000; Meinhard \& Foster, 2003a). Competition was increased as the commercialisation of public welfare services forced nonprofit service providers to compete with for-profit service providers for government contracts. The rate and extent at which these changes are occurring across provinces is different, but there is no doubt that the trend is evident in all provinces (Ismail, 1988; Hall \& Banting, 2000).

\section{The Ontario situation}

In the mid-1990s the people of Ontario elected a government espousing a "common sense revolution". The basic platform of this "revolution" was deficit reduction through the application of business principles of efficiency and competition to government and social services, while simultaneously cutting both individual and corporate taxes (Ontario Public Service Restructuring Secretariat, Cabinet Office, 1999). Per capita social spending dropped by more than $20 \%$ over a five year period from 1992-1997 (Ontario Public Accounts, 1989 - 2000). In this atmosphere of venerating business and efficiency, the government replaced operating grants with tenders for service contracts, encouraging the proprietary sector to compete with nonprofit organization, putting even more pressure on the voluntary sector (Brezanson, 1998). Clearly, a realignment was taking place that had an impact not only on the voluntary sector, but also on the Government-nonprofit relationship that characterized the previous decades.

\section{Survey of the Voluntary Sector}

In a survey of voluntary organizations Meinhard and Foster (2003b) found that among the 181 respondents from Ontario there was deep malaise in the sector at the precipitous way in which these changes were introduced, without any consultation, or lead time to adjust: Government acted alone, without obtaining community support before making policy changes. This left nonprofit organizations struggling to keep up with the increased demand for services that resulted from government devolution and the vacuum left by those organizations that were unable to continue to function in the face the budget cuts. Compounding this, the steep funding cuts reduced the range of options open to them to deal with the increased client-base.

Moreover, nonprofit organizations expressed a sense of despair as they feared these cutbacks would lead to a rapid increase in the already growing gap between the haves and the have. Their frustration was exacerbated by their conviction that corporations were not increasing their donations, especially not for services to the most marginalized members of society. All in all, leaders of nonprofit organizations felt an increased sense of vulnerability and were pessimistic about the future. Despite this, voluntary organizations, for the most part, were proactive in the way in which they faced these challenges. Although some had to resort to cost-cutting measures in the form of staff lay-offs and/or service cutbacks, the preferred strategies were to focus on marketing activities and public relations, to work more closely with other organizations, both nonprofit and forprofit, and to diversify funding sources, including undertaking some commercial activities (Meinhard \& Foster, 2003b). 


\section{The View from Government}

Following the voluntary sector survey, the team of Meinhard, Foster and Berger (2003c) conducted interviews with 20 civil servants in six government ${ }^{2}$ ministries that have close ties with the nonprofit profit sector. The objective of these interviews was to learn, first hand, how government bureaucrats viewed the ideological changes and the resulting new policies with respect to the voluntary sector, and how they defined their future relations with the sector. The interviews revealed a dedicated and caring civil service, trying their best to help their voluntary sector partners negotiate their way through the changing milieu.

Three themes emerged through analysis of the interviews. The first theme relates to increased demands for accountability. With the adoption of a business model to streamline government activity, ministries were required to cut spending and be more efficient and accountable to taxpayers. This forced them to demand new standards of behaviour from their nonprofit stakeholders in the form of tighter accountability requirements and performance measures. The second theme revealed that civil servants viewed themselves in a "brokering" role: one of interpreting policy to their constituents and helping them adapt and conform to the new realities, while at the same time conveying the concerns of their nonprofit constituents to policy strategists and political decision- makers in a non-consultative government. The third theme to emerge was the encouragement of collaboration and various forms of partnerships, particularly with the forprofit sector. In some ministries, tri-sector collaborations were encouraged in the form of matched funding and knowledge sharing (Meinhard et al., 2003c).

\section{Corporate Sector Perspective}

With government encouraging their nonprofit constituents to engage in partnerships with business firms, and with nonprofit organizations more actively pursing revenue diversification strategies that include corporate donations, the team of Meinhard, Foster and Berger decided to explore the perspective of the corporate sector vis a vis their role in civil society had to be investigated.

Historically, corporate involvement with the third sector has been minimal. In Canada, donations to charitable organizations account for only $3 \%$ of the total funding received by charitable agencies (Statistics Canada, 2003:23). The average rate of giving over the past five years is just over $1 \%(1.03 \%)$. This level of donations falls considerably short of the rates of donation reported in the U.S., where the tax rates are lower.

${ }^{2}$ Ministries of Health, Education and Training, Community and Social Services, Culture, Environment, Sports and Tourism. 
Recent reductions in corporate tax rates, from $28 \%$ in 2000 to $21 \%$ in 2004 (Dep't of Finance, 2002), should result in increased donations, however the statistics on corporate donations between 2002-2005 are not yet available. More recently, for-profit organizations have moved beyond straight philanthropy. Realizing the potential market benefits of supporting social causes, they have begun to engage in a variety of exchanges with for-profit organizations(Berger, Drumwright, Cunningham, 2005; Bloom and Hussein, 1995; Handleman and Arnold, 1999; Brown and Dacin, 1997; Ellen, Mohr and Web, 1997) These range from straight philanthropic exchanges, where the nonprofit agency receives no-strings-attached donations, to complex commercial partnerships that involve common strategic planning (Sinclair and Galeskiewicz, 1997; Sagawa and Segal, 2000; Austin, 2000).

While full partnerships between nonprofit and for-profit organizations in Ontario are still relatively uncommon (Schmid and Meinhard, 2000), the engagement of the for-profit sector in socially responsible activities is certainly growing. This growth is the joint result of consumer expectations and strategic opportunities. Consumers around the world are looking beyond governments for solutions to pressing social issues. They expect business firms to become full social citizens with shared responsibilities for maintaining, or even improving social welfare (Cone, 1997; White, 1997). Involvement in highly valued social causes has created a venue for some corporations to develop lasting relationships with targeted consumers, suppliers and employees, while making very positive contributions to the third sector. Some researchers suggest that these cross-sectoral relationships provide a powerful mechanism for the development of social capital (Berger et al.,2000). In particular, the development of "cause-based" relationships between consumers and for-profits, or between for-profits and non-profits may increase the levels of perceived trust, reciprocity and channels of information flow in society. As a result, society's productive capacity and its general ability to solve problems may be enhanced.

The following discussion focuses on how corporations view their emerging role in contributing to the well-being of civil society.

\section{Method}

Two population pools were used to attain our sample of organizations. First we accessed lists of Ontario-based organizations known to have prominent corporate social responsibility activities and categorized them according to industry (See Foster and Meinhard, 2002). We randomly picked at least two organizations from each of the following industries: Financial Services (3), Food and Beverage (2), Print Media (2), Technology (3), Retail (2), and Natural Resources $(2)^{3}$. Second, we created a contact list of Ontario-based organizations whose annual reports did not list any philanthropic activities. We tried to match the sample of philanthropic organizations with those that were not, according to industry. We were unable to get even a single non-philanthropic organization to consent to being interviewed on this topic.

\footnotetext{
${ }^{3}$ Brackets refer to the number of organizations from that industry in the final sample.
} 
One hour semi-structured, in-depth interviews were conducted with the managers or executives in charge of corporate philanthropy at fourteen Ontario-based corporations. The interviews were broad ranging, probing philanthropic strategies and practices, as well as philosophical outlook in terms of corporate social responsibility and the roles of the public, nonprofit and for-profit sectors in supporting civil society in Ontario. For each of the companies interviewed, detailed summaries of their philanthropic activities were recorded from public information sources such as web-sites, annual reports and printed materials distributed by the organizations.

The tape recorded interviews, conducted in the offices of the interviewees, were transcribed verbatim and the transcriptions were independently content analyzed by two trained coders and one of the co- authors. Key themes were identified, and when differences occurred among the raters, consensus was reached through discussion.

\section{Snapshots of the Corporations}

In order to protect the confidentiality of our interviewees, the names of the corporations have been changed. This section provides background information of each of the corporations that participated in this qualitative research including a general description of the company and its philanthropy profile in 2004. We obtained the data for these profiles from company Websites.

\section{Communications and Media}

City Post (CP). City Post champions its commitment to the community in which it operates, both in its daily publication and on its corporate website. This newspaper's strong philanthropic principles are based on the vision of a significant past publisher that has endured over time. Every aspect of this newspaper's business, from editorial to advertising standards, is guided by this philosophy. According to the company website, his philosophy includes a mandate of "social responsibility to readers and the people of [the city where it publishes]" including commitment to social justice, and a strong belief in the role of the state in regulating those areas of society that are not well serviced by private initiative. This former publisher's principles are well known by all the newspaper's staff. One tangible manifestation of this commitment is two strong centrally managed foundations under the auspices of the newspaper that focus mostly on children's charitable causes.

The Telegram (T). In circulation for well over a century, the Telegram offers a very large readership national, international, and business reporting, analysis and commentary. Its readers are generally affluent, and the newspaper advertises that it is read by a significant number of executives. Despite its strong presence in the media industry, the Telegram, in contrast to the City Post, has no section of its website devoted to its charitable endeavours. Its corporate section only discusses its industry role and provides details for potential advertisers. As it was acquired by a larger media empire in

2001, a thorough search of the parent company website was also completed, again with no published information on its web pages about any charitable endeavours. 


\section{Financial Services}

Multibank (MB). Multibank is a large, national financial institution comprising retail banking, wealth management services, and world markets. With 37,000 employees, the company provides financial services to more than nine million clients, including retail, small business clients, as well as corporate and investment banking clients. From its corporate homepage, Multibank prominently illustrates its commitment to community by offering two direct links to its public accountability statement, a document that details corporate donations, sponsorships, environmental commitment, and corporate governance strategy. There is also a direct message from the institution's CEO discussing this commitment. In 2004, Multibank contributed approximately $\$ 44$ million to charitable causes. It has been recognized for its approach to corporate social responsibility through a variety of awards and other honours. Notably, the website differentiates between donations (which it describes in dollar value) and sponsorships (which are described as an investment of the bank employee's "time, hearts, minds and money"). A listing of Multibank's sponsorships shows that it often maintains a role of "exclusive" or "premier" sponsor.

Queen's Bank(QB). With approximately 4.5 million clients, the Queen's Bank is an industry leader in personal and commercial banking, brokerage operations, mutual funds, as well as travel insurance, creditor products and individual disability insurance. In 2004, the bank gave \$39 million to charitable causes and these funds are administered through a foundation. It also provides a public accountability statement that includes a comprehensive listing of every nonprofit organization it has funded in the current fiscal year, divided by focus area and by also by region. In addition, it posts giving guidelines to aid nonprofits searching for donations. Like Multibank, it also differentiates its donations from its sponsorship activities. The Queen's Bank website defines a donation as "funds given to a not-for- profit organization, for which a tax receipt is issued"; and a sponsorship is defined as "a partnership negotiated with another organization (sometimes a not-for-profit organization) for marketing purposes."

Trenalife (TL). Trenalife is primarily a life and health insurance company, with additional financial products such as pensions, mutual funds, annuities, group benefits and long-term care. Based in Canada, the corporation is over 100 years old, currently managing operations in 19 countries and territories. In 2004, Trenalife gave more than $\$ 15$ million in donations to nonprofits, which it further break down as $73 \%$ donations and $27 \%$ sponsorships. Interestingly, despite this breakdown, these terms appear to be used interchangeably on the Website. It categorizes all funding recipients as "partners." The company's public accountability statement includes mention of its status as an Imagine company and active web links to each partner's website. The website states a policy of "giving forward" in order to support "important emerging issues to make a positive difference for the future." All potential partners must complete a very lengthy application form, available on the website with complete and detailed instructions.

\section{Retail Services}


Always Canadian Department Store (AC). Always Canadian is a large department store retailer with 70,000 employees in every region of Canada. Its website states its "culture is grounded in a commitment to take into account the social needs and issues impacting communities..." It commits over $\$ 11$ million each year to charitable initiatives, through a series of foundations and retailer- focused fundraising initiatives. Each year it publishes a comprehensive Corporate Social Responsibility Report that details its accomplishments and lays out its objectives for the next year.

Coffee First (CF). Coffee First is a nationwide coffee house franchise. As the majority of Coffee First's product is purchased from developing countries, the company seeks to "give back" to these nations. Its most notable act of corporate philanthropy is a relationship (established in 1996) with an adoption-style development agency. Each retail location sponsors a child through this program.

\section{Technology}

Kanwintel (KW). Involved in communications technology, Kanwintel offers packet, optical, wireless and voice technologies to governments, businesses and individuals. In operation for over one hundred years, Kanwintel strives to leverage its expertise in broadband technology to address community challenges. The company website also states its intention to focus its community programs to enhance relationships with customers and employees. A cornerstone of its program is an online education partnership to offer learning skills to teachers. Despite continuing financial difficulties and a sharply declining stock price, it continues to allocate funds to philanthropic activities.

Worldwide Tech (WT). Worldwide Tech is a provider of advanced information technology products and services. The company employs over 300,000 worldwide and takes pride in its strong leadership, honesty, expertise and customer service. It provides up-front information about its community relations strategy in Canada on its "About Worldwide Tech" webpage, claiming its "corporate donation strategy combines our leading-edge technology and our people in effective partnership to bring solutions to the systemic problems that impact society, business, and quality of life." It reports corporate contributions at more than $\$ 2.8$ million in the form of technology and cash.

Canwork Networks (CN). Canwork Networks is a diversified Canadian involved in providing the technology for broadband and wireless communication, cable television services, and media holdings such as radio, television and publishing. In terms of community support, Canwork supports a range of initiatives, from national programs to grassroots charities. Its website has information on 12 sectors of funding, including arts and entertainment, education, health and wellness, safety, sports and youth. In the same location, it also provides a very short three-point guideline for potential applicants, along with contact information for its community relations manager. While its website does not provide any information about the level of 2004 corporate donations, our interviewee noted that the Canwork Foundation has a budget of \$25 million. 


\section{Natural Resources}

Oilcan (OC). Founded as a Crown corporation in 1975, Oilcan is an integrated oil and gas company that explores for, develops, produces and markets crude oil and natural gas. It has nearly 4,800 employees. Its homepage has prominent links to its community and environmental strategy. In 2004, Oilcan invested about $\$ 6.8$ million in nonprofit organizations in four sectors education, environment, health and community services, and arts and culture. Each year, Oilcan produces a "report to the community", available on its website for the current year (as well as the previous four years), which details its activities in the area of corporate social responsibility and philanthropy.

Inex (IX). Aspiring to be the world's largest nickel producer, Inex has mining facilities in both hemispheres and operates on four continents, with a worldwide marketing network that extends to over 40 countries. The company is over 100 years old and has almost 11,000 employees. Its homepage has a link to a video that focuses on its role as a good neighbour in foreign countries. The Website also contains a social responsibility report that breaks down its 2004 activities, but does not include an overall dollar figure. Our interviewee indicated that the philanthropy budget was \$1.4 million US in 2003.

\section{Food and Beverage Manufacturers}

Lakeside Breweries (LB). This longstanding Canadian brewery has operations in Canada, Brazil and the United States. Its Website notes that its founder had a keen sense of social responsibility and this commitment to giving back to the community continues to be part of the company culture and values. As a manufacturer of alcohol operating in a regulated environment, Lakeside directs its community investment donations to programs that benefit adults, not children. Its website also highlights Lakeside's status as an Imagine company.

Whiterock Foods (WF). Whiterock is Canada's leading food processing company, with exports to over 80 countries. They have approximately 23,000 employees and over 120 processing plants. As noted on the Website, Whiterock is an Imagine company and donates as a minimum, one per cent of pre-tax profits to health, social and educational research and services in the form of both cash and in-kind gifts.

\section{Results}

The range of topics covered in the interviews was broad and many themes were identified by our coders. This discussion centres on only those themes that relate to the corporate sector's perspectives on civil society and the roles of the various sectors, especially their own, in ensuring a healthy future. In another paper, we discuss the different emerging strategies that define the corporate sector's relationship with individual voluntary organizations. 


\section{Types of relationships and extent of contact with the nonprofit sector}

There is great variation among the organizations with respect to the extent of their contact with and type of involvement in the nonprofit sector. Banks (MB, QB) are clearly the most involved, in terms of the dollar value of their support, the multiplicity of relationships, and the variety of programs. Other organizations are only involved in a single project (CF) or pursue programs only in the communities in which they were located (IX) or donate only to large projects (OC). Some organizations are focused in their giving, linking their support and donations exclusively to projects directly related to their product (KW, TL), their employees' needs (WF, TL), or giving "in kind" support by donating their products for educational purposes (WT). Others are eclectic in their giving, choosing their charities at the sole discretion of their CEOs (T, CN). Several have their own charities or charitable foundations $(\mathrm{CP}, \mathrm{AC}, \mathrm{QB}, \mathrm{MB})$.

Most organizations prefer longer term relationships, or partnerships, to ad hoc giving. However, there are still many corporations whose primary contact with the nonprofit sector is straight philanthropy (T). Some of those are now considering "partnership" strategies (TL, WF). Although there is no consensus regarding the term partnership, the implied meaning refers to something that is longer lasting and provides mutual benefit. These partnerships range from setting up a retail outlet at a hospital to the benefit both $(\mathrm{CF})$, to joint fundraising projects with half the proceeds going to their own foundations, and half to their nonprofit partners $(\mathrm{AC}, \mathrm{CP})$, to organizing events for the benefit of charities (MB) to being a "community partner" in large community wide projects (LB, AC). Three companies fostered partnerships with nonprofit organizations in the truest sense, where the company and the NPOs collaborated, brain stormed and developed a project together. $\mathrm{CP}$ worked on a project to improve libraries, $\mathrm{KW}$ developed an online technology teaching program and TL occasionally helps NPOs with the start-up. We discuss these various strategies in detail in another paper.

The shift from ad hoc donating to larger projects provides better exposure for corporations, thus increasing brand awareness. The downside of this is that the smaller organizations, those very organizations most vulnerable to government cutbacks, are unlikely to be the recipients of corporate donations.

\section{Obligations of the three sectors in a changing environment}

There is a consensus among our respondents that the last decade has been a turbulent one for the nonprofit sector. They have felt this directly, inundated with more requests than they can handle.

That's what we are hearing a lot, from charitable partners, is that the money is not there anymore from the government, and that's why they are coming after corporations and the private sector, and I think now the corporations and the private sector are feeling the crunch, it's everywhere, they are coming at you from every angle, every charitable organization from grass-root to the most established and well known and successful...(TL) 
It becomes very annoying as a corporation to see all these requests.(LB)

But at the same time they believe that they have some kind of an obligation to give back.

I think all big business has an obligation to not just help the end user, but to give as much assistance as they can to the middle groups, to the nonprofits and the charities to help $(C P)$

I think it is extremely important that we continue to contribute [to the nonprofit sector] because I really don't think that the non-profit can survive without [support]. $(L B)$

Despite this, they do not believe that they should be replacing government as the key supporter, or even that they should be replacing the lost government funding.

I think that ... (to)...push responsibility on the corporations because the government doesn't want.. (to support)...is wrong $(\mathrm{CN})$

But there are still severe, severe social problems in Canada and I think the government needs to not step back because we have to do more (WT)

There is even some anger expressed at the extent of government cutbacks and abelief that government should be doing more.

... the government I mean they are cutting so much funding to the non-profit sector and it makes me cringe sometimes because there are some wonderful programs like day-care suffering and I would love to see them do more for battered women's shelters. How do they change and protect these poor women and children. So I think there is a huge responsibility there for government and I am not sure that in my opinion they are taking responsibility for it. I think they try to dodge it whenever they can. $(L B)$

In fact, the corporations do see a continued major role for government in the nonprofit sector.

I think they (the government) need to be involved in or should be involved in ... creating opportunities for nonprofits to be able to better utilize their resources, such as the match programs and such as subsidized positions, whether it's youth training or youth experience or whatever that field is that they can take advantage of government programs $(C P)$

Government is seen as the only sector who can pull it all together, although the same respondent was doubtful of government's ability do so. 
I think you have to almost point your finger at the government, because who else can touch all those areas (TL)

They are very broad, they can't get down to business I think sometimes and that might be dollars, that might be lack of resources or understanding or what have you. (TL)

This perception of government's inefficiency is echoed by others

The government is the most inefficient operator in terms of what they deliver for the money spent. No, of course I want them out (WF)

not only in terms of money, but also in terms of overall vigilance.

I don't believe that government spends enough time in monitoring the charitable and nonprofit sector. There are two areas that I think the government is falling short on. One is, it's very easy to obtain a charitable or nonprofit license.... I think that needs to be tightened up. And I also think that the reporting back ... [is an] area that I think the government really needs to be involved in. $(C P)$

Although there was universal acknowledgment of the importance of the nonprofit sector, there was criticism as well.

I think obviously most of them out there are doing a terrific job. But I also wonder if they couldn't streamline a little bit because it is almost overwhelming when you have ten organizations all doing wonderful things but maybe to coordinate things a little bit. (LB)

What some charities don't quite get is that we are trying to take the training wheels off, so we've had to pull back, and sometimes it's not as pleasant as you'd like. (OC)

\section{Accountability and Trust}

Despite this, there seems to be a lot of trust by the corporate sector vis a vis the nonprofit sector. This is most clearly expressed in their loose requirements for accountability as to how the dollars are spent. Some corporations rely solely on the reputation of the organizations,

We looked for a way to get support back to the areas from where we were getting our coffee. We wanted to do it with a responsible group ... and that's how we chose them [the particular charity that they donate to] ... a very responsible organization....I do believe that a considerable amount of trust goes into this as well. So, we don't audit them. $(C F)$

others practice what can be called "front-end" accountability. 
Because the accountability I think belongs to the front end not the back end. And it is up to me to make sure that the \$20,000 that I've given you is going towards where they say it is going to go, [and that] it is actually going to get there and it is going to do good work. (WF)

You would have to already have established yourself as a registered charity. In other words, you would need to have gone through someone else's hoops already. (MB)

The banks in our sample both treat nonprofit organizations looking for donations, as businesses looking for small loans; they investigate the credibility of these groups before deciding to donate to or partner with an organization.

And what we also don't want, because we have fiduciary responsibility, is to end up funding something that isn't something it pretends to be. So there needs to be due diligence around that. So much as we would do with a business we would ask fairly pointed questions about expertise (MB)

We do a background check of the organizations we give donations to, much as we do for small businesses asking for loans. $(Q B)$

Another way organizations decide where to donate is to determine the credibility of an organization by looking at the ratio of administrative costs to revenues.

We would like to see the highest possible portion of the benefit go to the charities, not to the administrative costs. (MB)

Several organizations request to see annual reports, especially if the organization wants renewed funding, however this is done mostly informally

We ask them to keep in touch and send an annual report $(L B)$

Only two corporations consistently require audited financial statements: one asks for this only from unfamiliar nonprofit organizations (WF), and another asks for audited financials if the donation is larger than $\$ 20,000$ (AC). Other organizations have a sliding scale of accountability depending on the amount of the donation and/or the reputation of the organization.

Well, we ask them to let us know what they are doing, tax receipts of course, because we need it for foundations. But it all depends on the size of the request as well. I mean if we are giving somebody a $\$ 500$ donation I mean we don't...we just can't...but for giving somebody a \$25,000 donation well then, yes we do. (AC)

The move to more active partnerships as opposed to pure philanthropy is another way in which some organizations feel they have greater control over what happens with their donations. 
With the new non-profit that we are working with the relationship is so tight that someone from our office is probably in their office every other day. So the report isn't as needed because we communicate regularly. I mean basically we are working towards the same goal. So we use each other's resources. We have conference calls; it's more like a little piece of our team. $(K W)$

\section{Partnerships}

The term partnership is used very loosely among our respondents. Most of them do refer to some of their relationships with nonprofit organizations as partnerships, distinguishing between straight donations on the one hand and sponsorships, which also involve monetary donations, on the other.

[We] have sponsorship activities ... that ... differ from the charitable activities.

The preference for sponsorship lies in the increased exposure it provides an organization, linking it to a worthy cause. Although the incentive is often to gain some competitive advantage by attracting new clients, organizations have also found it beneficial in increasing employee pride and satisfaction.

People are asking for that [more corporate involvement in charitable activities], communities are asking for that, that's who they want to do their business with. And if you are not going to reach your stakeholders' needs or meet them, they are not going want to do business with you. (TL)

I look at some of our partnerships that just do some really important work and we're in there at sort of an upper level. And we're recognized for that. It doesn't have to be an Oilcan program, but we'd like our logo to be there, so people see, it's a great initiative and Oilcan is involved. (OC)

The majority of organizations in our study have some kind of employee volunteering project that they support in various ways: guaranteeing to top up the fundraising efforts of their employees, giving employees paid time off, rewarding employees by contributing to their favourite groups, and providing in-kind support. These employee projects often become long-term partnerships. T

We have an employee volunteer program where if you volunteer your personal time, 48 hours a year, we'll cut a cheque for five hundred dollars to the charity that you work for. That's worked incredible well. (OC)

We enter into partnerships with some charities in terms of we make donations to them, but we also get the employees involved in supporting the charities either in fundraising, providing volunteering hours, whatever the case may be. (AC) 
We have a large number of employees who really want to get involved in fundraising for the [local] hospital. We guarantee the hospital they will raise $X$ dollars every year during the course of this pledge. If they don't the company will cover the short fall. $(W F)$

The high-tech firms in our sample are both involved in partnerships with educational institutions

Education definitely is our number one focus for our brand program, but for the employees, they are more on the health and wellness and environmental area, and also on the matching grant program (WT)

Our sole project we are funding is a group called Kids On-line. It's a non-profit that creates content for teachers through a major database of on-line resources that they can use in the classroom. [We support] professional development, seminars and programs around that so they know how to use that. $(K W)$

Only one organization, Inex, was in involved in partnerships involving all three sectors. This was a natural resource company that helped build schools and hospitals in the areas in which they had operations. Another was moving away from partnerships with single organizations to working with several organizations for the benefit of the community.

Giving back to small grass root communities across Canada to help fix up and revitalize recreational facilities. (LB)

\section{Discussion and Conclusions}

During the past decade, nonprofit organizations have mobilized to diversify their resources in response to government funding cutbacks (Meinhard \& Foster, 2003a; Foster \& Meinhard, 2005). This diversification has taken several forms including: increased commercial activities, fees for service, increased marketing and fundraising campaigns, and the establishment of partnerships with nonprofit and for-profit organizations. The most recently available statistics indicate that the corporate sector has responded by more than doubling their support of the voluntary sector from $\$ 1.2$ billion in 1996 (Standing Committee on Finance, 1996) to $\$ 2.8$ billion in 2003(Statistics Canada, 2003:23), while during the same period, government support increased only $12 \%$ from $\$ 48.9$ billion to $\$ 54.1$ billion. Thus the proportion of government support decreased from $56 \%$ to $49 \%$, while the proportion of corporate support increased from $1 \%$ to $3 \%$. The remaining shortfall in government support was made up through a 50\% increase in earned income, from $\$ 26$ billion to $\$ 39$ billion, accounting for the additional $4 \%$.

Analysis of the interviews revealed a wide range of different approaches and practices to corporate philanthropy. Our respondents believe in the importance of a vibrant voluntary sector and agree that it is time for corporations to "give back" to their communities. To this end, their organizations try to offer support in different, and at times, innovative ways, both through direct 
giving and by encouraging and facilitating employee volunteer programs. However, they are unable to comply with the growing number of requests resulting from government cutbacks. Some respondents expressed fear that nonprofits are becoming too dependent on corporate donations and there were complaints that government is derelict in its support of essential social and cultural services. While corporate donors seem ready to increase their support of worthy causes and charities, in their view the onus for providing social, educational and cultural services still lies with the government.

It seems that the government's message to nonprofit organizations, to create more partnerships, clearly enunciated in the interviews conducted with the civil servants by Meinhard, Foster and Berger (2003), has been heard by both the nonprofit and for-profit sector. And while government has decreased their funding, they have also burdened their recipients with increased reporting requirements. A current study being conducted by the team of Meinhard, Foster and Berger, indicates that this is causing much grief in the nonprofit sector, especially among smaller organizations, to the extent that some organizations have stopped applying for certain government grants because they do not have the necessary human or financial resources to fulfil the reporting requirements. This stands in contrast to the accountability requirements of corporate donors. There seems to be more trust and a greater recognition of the onus such reporting can put on small organizations.

The trend seems to be moving towards a more even distribution of the responsibility for ensuring civil society, although there is an unequivocal agreement in the corporate sector that the onus is still the government's to bear. Government can withdraw only so far. Corporations do not see it as their responsibility to become much more involved than they are in supporting civil society. Only one organization in our sample was involved in three sector partnerships, but new research is pointing to the importance of these collaborations in tackling large societal and/or environmental problems and particularly, crises (Googins \& Rochlin, 2000; Hyde, et al., 2002; Kapucu, 2005; Rondinelli \& London, 2003).

\section{References}

Austin, J. E. (2000). Strategic collaboration between nonprofits and businesses. Nonprofit and Voluntary Sector Quarterly, 29 (1), 69-97.

Berger, I.E., Cunningham, P.H. \& Drumwright, M.E. (2005) Social Alliances: Company/nonprofit collaboration. California Management Review 47(1), 58-90

Bloom, P.N. \& Hussein, P.Y. (1995). Benefiting society and the bottom line. Marketing Management 4, 8-19.

Brezanson, K. 1998 Act in haste: The style, scope and speed of change in Ontario. Ottawa : Caledon Institute of Social Policy. 
Brown, T.J. \& Dacin, P.A. (1997). The company and the product: Corporate association and consumer product responses. Journal of Marketing 61, 68-84.

Cone, C. (1997). Cause-related marketing trends report. Boston: Cone Communications, Inc.

Ellen, P., Mohr, L. \& Web, D. (1997). Can retailers benefit from cause marketing?. Working Paper, Georgia State University.

Foster, M.K. \& Meinhard, A.G. (2005). Diversifying revenue sources in Canada: Are women's voluntary organizations different? Nonprofit Management and Leadership, 16 (1), 43-60.

Foster, M. \& Meinhard, A. (2002). Corporate social responsibility in the Canadian context: The new role of corporations in community involvement and social issues. Presented at the annual conference of the Association for Research on Nonprofit Organizations and Voluntary Action, Montreal, PQ

Googins, B.K. \& Rochlin, S.A. (2000). Creating the partnership society: Understanding the rhetoric and reality of cross-sectoral partnerships. Business and Society Review 105(1), 127-144

Hall, M. \& Banting, K.G. (2000). The nonprofit sector in Canada: An introduction. In K.G. Banting (Ed.), The nonprofit sector in Canada: Roles and relationships (pp. 1-28). Montreal and Kingston: School of Policy Studies, Queen's University.

Handleman, J.M. \& Arnold, S.J. (1999). The role of marketing actions with a social dimension: Appeals to the institutional environment. Journal of Marketing 63, 33-48.

Hyde, C., Meyer, M. \& Cook, D. (2002). A new twist in nonprofit, for-profit, and public sector relationships: The community benefits district. International Journal of Sociology and Social Policy 22(9-10), 55-76

Ismail, J.S. 1988. Privatization of social services: A heuristic approach. In Ismail, J.S. \& Vaillancourt, Y. (Eds.) Privatization and Provincial Social Services in Canada: Policy, Administration and Delivery. Edmonton: University of Alberta Press.

Jeffrey, B. (1999). Hard Right Turn: The New Face of Neo-Conservatism in Canada. Toronto: HarperCollins Publishers, Inc.

Kapucu, N. (2005). Interorganizational Coordination in Dynamic Context: Networks in Emergency Response Management. Connections 26(2), 33-48

McBride, S. \& Shields, J. (1997). Dismantling a Nation: The Transition to Corporate Rule in Canada. Halifax: Fernwood Publishing. 
Meinhard, A. \& Foster M. (2003a). Differences in the response of women's voluntary organizations to shifts in Canadian public policy, Nonprofit and Voluntary Sector Quarterly, 32 (3), 366-396.

Meinhard, A. \& Foster, M. (2003b). Responses of Canada's voluntary organizations to shifts in social policy: A provincial perspective [Online]. ISTR Conference Working Papers, Vol. III. Available: http://www.jhu.edu/ istr/conferences/capetown/volume/meinhard.pdf

Meinhard, A., Foster, M. \& Berger, I. (2003). The evolving relationship between Government and the Voluntary Sector in Ontario. Presented at the annual conference of the Association for Research on Nonprofit Organizations and Voluntary Action, Denver, CO.

Ontario Public Accounts (1989-1990 to 1999-2000). Summary of Expenditure by Standard Accounts Classification and Ministry .

Ontario Public Service Restructuring Secretariat, Cabinet Office. (1999) Transforming Public Service for the $21^{\text {st }}$ century. Government of Ontario.

Pal, L.A. (1997). Civic re-alignment : NGOs and the contemporary welfare state. In R.B. Blake, P.E. Bryden, and J. F. Strain (Eds.), The Welfare State in Canada: Past, Present and Future. Concord: Irwin Publishing.

Rice, J. J. \& Prince, M. J. (2000). Changing Politics of Canadian Social Policy. Toronto: University of Toronto Press.

Rondinelli, D.A. \& London, T. (2003). How corporations and environmental groups cooperate: Assessing cross-sector alliances and collaborations. Academy of Management Executive 17(1), 61-76

Ryan, W.P. (1999). The new landscape for nonprofits.” Harvard Business Review 77,127-137.

Sagawa, S. and Segal, E. (2000). Common interest, common good: Creating value through business and social sector partnerships. Cambridge: Harvard Business School Press.

Schmid, H. \& Meinhard, A.G. (2000). A comparative analysis of emerging partnerships between corporations and nonprofit social service organizations in Canada and Israel. Presented at the annual conference of the Association for Research on Nonprofit Organizations and Voluntary Action, New Orleans, LA.

Sinclair, M. and Galaskiewics, J. (1997). Corporate-nonprofit partnerships: Varieties and covariates. New York Law School Law Review, 41,1059 - 1090.

Standing Committee on Finance, (1996). 1997 Budget and beyond. 
Statistics Canada, (2003). Cornerstones of community: Highlights of the National Survey of Nonprofit and Voluntary Organizations, Catalogue No. 61-533-XIE.

Weisbrod, B.A. (1995). Do private firms, church-related nonprofits and other nonprofits behave differently? Department of Economics, Northwestern University, Evanston, Il.

White, G. (1997). The not-for-profit and the private sectors in the 1990's ... or how 'Birkenstock' and 'Pinstripe' need each other! Toronto: Market Vision Group. 